\title{
Inhibition of Rat Vascular Smooth Muscle Proliferation In Vitro and In Vivo by Bone Morphogenetic Protein-2
}

\author{
Takashi Nakaoka, ${ }^{\star}$ Koichi Gonda, ${ }^{\ddagger}$ Teruhiko Ogita, ${ }^{\star}$ Yoko Otawara-Hamamoto, ${ }^{\S}$ Fujiko Okabe,, ${ }^{*}$ Yuji Kira," Kiyonori Harii,, \\ Kohei Miyazono, ${ }^{* *}$ Yoh Takuwa," and Toshiro Fujita* \\ *Fourth Department of Internal Medicine, School of Medicine, University of Tokyo, Tokyo 112, Japan; ${ }^{*}$ Department of Plastic Surgery, \\ ${ }^{\S}$ School of Health Sciences and Nursing, and ${ }^{\|}$Department of Cardiovascular Biology, Faculty of Medicine, University of Tokyo, Tokyo \\ 113, Japan; "Division of Cardiology, Showa General Hospital, Tokyo 187, Japan; and **Department of Biochemistry, the Cancer Institute, \\ Japanese Foundation for Cancer Research, Tokyo 170, Japan
}

\begin{abstract}
Vascular proliferative disorders are characterized by the proliferation of vascular smooth muscle cells (SMCs) and excessive extracellular matrix synthesis. We found that bone morphogenetic protein-2 (BMP-2) inhibited serumstimulated increases in DNA synthesis and cell number of cultured rat arterial SMCs in a fashion quite different from that in the case of transforming growth factor- $\beta 1$ (TGF- $\beta 1$ ). In addition, TGF- $\beta 1$ stimulated collagen synthesis in SMCs, whereas BMP-2 did not. In an in vivo rat carotid artery balloon injury model, the adenovirus-mediated transfer of the $B M P-2$ gene inhibited injury-induced intimal hyperplasia. These results indicate that BMP-2 has the ability to inhibit SMC proliferation without stimulating extracellular matrix synthesis, and suggest the possibility of therapeutic application of BMP-2 for the prevention of vascular proliferative disorders. (J. Clin. Invest. 1997. 100:2824-2832.) Key words: adenovirus - atherosclerosis - balloon injury • smooth muscle cell $\bullet$ transforming growth factor
\end{abstract}

\section{Introduction}

The proliferation of vascular smooth muscle cells (SMCs) ${ }^{1}$ is a common feature associated with vascular proliferative disorders such as atherosclerosis and restenosis after balloon angioplasty. A number of growth factors and growth inhibitors are detected within vascular proliferative lesions. Among them, platelet-derived growth factors, basic fibroblast growth factor, and insulin-like growth factor-I are strongly mitogenic for

Address correspondence to Dr. Takashi Nakaoka, Fourth Department of Internal Medicine, School of Medicine, University of Tokyo, 3-28-6 Mejirodai, Bunkyo-ku, Tokyo 112, Japan. Phone: 81-3-39431151; FAX: 81-3-3943-3102; E-mail: nakaoka-DIS@h.u-tokyo.ac.jp Y. Takuwa's present address is the Department of Molecular and Cellular Physiology, School of Medicine, University of Tokyo and the Foundation for Advancement of International Science (FAIS), Tokyo 113, Japan.

Received for publication 28 February 1997 and accepted in revised form 17 October 1997.

1. Abbreviations used in this paper: BMP, bone morphogenetic protein; $\mathrm{CHO}$, Chinese hamster ovary; dpm, decay per minute; I/M, intimal to medial; SMC, smooth muscle cell; X-gal, 5-bromo-4-chloro3 -indolyl- $\beta$-D(-)-galactopyranoside.

J. Clin. Invest.

(C) The American Society for Clinical Investigation, Inc. 0021-9738/97/12/2824/09 \$2.00

Volume 100, Number 11, December 1997, 2824-2832

http://www.jci.org
SMCs, and may play critical roles in the in vivo proliferation of SMCs (1). On the other hand, it has also been reported that atherosclerotic lesions once established are capable of regression with extensive therapies (2). Natriuretic peptides, nitric oxide, and interferon- $\gamma$ were shown to have growth-suppressive actions on SMCs $(3,4)$. Therefore, the process of SMC proliferation appears to be a dynamic one, in which SMC proliferation is subject to the concomitant effects of these growth regulatory molecules in atherosclerotic lesions.

TGF- $\beta 1$ is a bifunctional growth regulator of vascular SMCs. It stimulates or inhibits the growth of SMCs, depending upon the target cells, the cell culture conditions, the presence of other growth-regulatory molecules, the order of their addition, and the TGF- $\beta 1$ concentration used $(5,6)$. Bone morphogenetic proteins (BMPs), which belong to the TGF- $\beta$ superfamily, were originally detected as bone-inducing activity (7). In addition to bone induction, BMPs regulate diverse biological processes, and are involved in the development of nearly all organs and tissues. The action of BMPs as potent ventralizing factors by counteracting dorsalizing factors during gastrulation, which was first revealed in Xenopus embryos, is conserved between insect and vertebrate embryonic development (8). BMPs exhibit antiproliferative activities toward certain cell types $(9,10)$. Recently, BMP-2 and BMP-6 were reported to be detected in human atherosclerotic coronary arteries (11, 12). They are implicated in the atherosclerotic artery calcification through the analogy between calcification and bone formation; however, their biological activities towards vascular cells remain uncertain.

In this study, we demonstrated that BMP-2 has a potent inhibitory action on the growth of cultured rat aortic SMC. In addition, we showed that the adenovirus-mediated transfer of the $B M P-2$ gene into an injured artery inhibited SMC proliferation in vivo as well as in vitro, using a rat carotid balloon injury model.

\section{Methods}

Materials. Recombinant human BMP-2 and BMP-7/osteogenic protein-1 were kindly provided by Dr. T.K. Sampath, and recombinant human TGF- $\beta 1$ was purchased from R\&D Systems, Inc. (Minneapolis, MN). BMP- 2 and TGF- $\beta 1$ were dissolved in $0.1 \%$ BSA in $4 \mathrm{mM}$ $\mathrm{HCl}$ and stored at $-30^{\circ} \mathrm{C}$ until use. Recombinant human activin $\mathrm{A}$ was provided by Dr. Y. Eto and dissolved in DME containing $0.1 \%$ BSA for storage. $\left[6-{ }^{3} \mathrm{H}\right]$ Thymidine and $\mathrm{L}-\left[2,3-{ }^{3} \mathrm{H}\right]$ proline were obtained from DuPont NEN (Boston, MA). A replication-deficient adenovirus carrying the Escherichia coli $\beta$-galactosidase gene, AxCALacZ, and a cosmid, pAxcw, was kindly provided by Dr. I. Saito (13).

Construction of an adenovirus carrying the BMP-2 gene. A replication-deficient adenovirus carrying the $B M P-2$ gene, AxCABMP2, was created as follows. EcoRI and SalI digested cDNA (1.26 kbp) containing the complete coding region of human BMP-2 (7) was 
blunt-ended and cloned into pCAGGS (14). Then, the DNA fragment $(3.5 \mathrm{kbp})$ containing the $C M V$-IE enhancer, the chicken $\beta$-actin promoter, an intron, the coding region of $B M P-2$, and rabbit $\beta$-globin polyadenylation signal was blunt-end ligated into SwaI site of a cosmid, pAxcw. The resulting cosmid, pAxBMP2, was cotransfected to the 293 embryonic cell line with an EcoT221-digested DNA-TPC (from Ad5dlx) to generate a replication-deficient adenovirus, AxCABMP2 $(15,16)$. The obtained viral clones were isolated, screened for the $B M P-2$ insert, and propagated. For in vitro and in vivo experiments, the viruses were purified through a $\mathrm{CsCl}$ cushion, titrated, and stored in PBS containing $10 \%$ glycerol at $-80^{\circ} \mathrm{C}$ as described (17).

Cell culture. Rat aortic SMCs were prepared from 8-wk-old Wistar rats by the explant method (18), and were grown in DME supplemented with $10 \%$ FBS (Life Technologies Inc., Tokyo, Japan), $100 \mu \mathrm{g} / \mathrm{ml}$ of streptomycin, and $100 \mathrm{U} / \mathrm{ml}$ of penicillin at $37^{\circ} \mathrm{C}$ under a $95 \%$ air $/ 5 \% \mathrm{CO}_{2}$ atmosphere. Cultured SMCs from passages 4-8 were used for all experiments.

Measurement of $\left[{ }^{3} H\right]$ thymidine incorporation into DNA of SMCs. Rat aortic SMCs seeded onto flat-bottomed 24-well tissue culture plates (Falcon Labware, Oxnard, CA) were grown until 70$90 \%$ confluence and then made quiescent by culturing in DME containing $0.1 \%$ BSA for $60 \mathrm{~h}$. Then, the cells were stimulated with 1 or $10 \%$ FBS in the presence of various concentrations of BMP-2, BMP-7, TGF- $\beta 1$, or activin $A$, followed by pulse-labeling with $37 \mathrm{kBq} / \mathrm{ml}$ of $\left[{ }^{3} \mathrm{H}\right]$ thymidine in $500 \mu \mathrm{l}$ of the same medium for $2 \mathrm{~h}$. In some experiments, BMP- 2 or TGF- $\beta 1$ was added at various time points after stimulation with FBS. $\left[{ }^{3} \mathrm{H}\right]$ Thymidine incorporated into the DNA of the cells was determined by the TCA precipitation method involving liquid scintillation counting as described (19), and expressed as decay per minute $(\mathrm{dpm})$ or percentage of control. To determine the rate of $\left[{ }^{3} \mathrm{H}\right]$ thymidine incorporation into DNA of SMCs transfected with replication-deficient adenoviruses, SMCs seeded onto 24-well plates were grown until 70-90\% confluence, exposed to $200 \mu$ l of DME with $0.5 \%$ FBS containing the indicated mois of the viruses for $2 \mathrm{~h}$, and then serum-deprived for $60 \mathrm{~h} .\left[{ }^{3} \mathrm{H}\right]$ Thymidine incorporated into DNA was determined at $24 \mathrm{~h}$ after the stimulation with $1 \%$ FBS. All experiments were performed in triplicate and were repeated at least three times.

Measurement of cell number. SMCs seeded onto 24-well plates at $8 \times 10^{3}$ cells per well were maintained in DME containing $10 \%$ FBS for $24 \mathrm{~h}$ for their attachment to the plates. Then the medium was replaced, and the cells were grown in DME containing $10 \%$ FBS and various concentrations of recombinant BMP- 2 or TGF- $\beta 1$ for $3 \mathrm{~d}$. The medium was changed once at $2 \mathrm{~d}$. At the indicated time points, the wells were washed once with PBS, and then the cells were detached by maintenance in $200 \mu$ l of PBS containing $0.05 \%$ trypsin and $0.53 \mathrm{mM}$ EDTA at $37^{\circ} \mathrm{C}$ for $5 \mathrm{~min}$. The cells were counted (four times per well) using a hemocytometer, in quadruplicate. Cell viability was assessed by the trypan blue exclusion method.

Measurement of collagen synthesis. SMCs seeded onto 12-well tissue culture plates were grown until $70-90 \%$ confluence, and then serum-deprived in an $\alpha$-complementation of minimum essential medium $(\alpha-$ MEM) for $24 \mathrm{~h}$. The cells were then treated with the indicated concentrations of TGF- $\beta 1$ or BMP- 2 in the $\alpha$-MEM containing $50 \mu \mathrm{g}$ ascorbic acid and $50 \mu \mathrm{g} \beta$-aminopropylnitrile for $24 \mathrm{~h}$. Then, the cells were labeled with $185 \mathrm{kBq} / \mathrm{ml}$ of $\left[{ }^{3} \mathrm{H}\right]$ proline in $1 \mathrm{ml}$ of the medium for $3 \mathrm{~h}$. Collagen synthesis by the cells was determined as described (19).

Western blot analysis. The conditioned media of cells infected with adenoviruses were collected and centrifuged at $4^{\circ} \mathrm{C}$ for $5 \mathrm{~min}$ at $10,000 \mathrm{~g}$ to remove cellular debris. The supernatants were brought to $62.5 \mathrm{mM}$ Tris- $\mathrm{HCl}, \mathrm{pH} 6.8,10 \%$ glycerol, $2 \%$ SDS, $5 \% \beta$-mercaptoethanol, and $0.002 \%$ bromophenol blue and were boiled at $92^{\circ} \mathrm{C}$ for $3 \mathrm{~min}$. Aliquots of the samples $(20 \mu \mathrm{l})$ were separated on $15 \%$ SDSpolyacrylamide gels and proteins were transferred to nylon membranes (Immobilon-P; Millipore Corp., Bedford, MA). Immunostaining of BMP-2 was performed by the avidin-biotin complex method using an $\mathrm{ABC}$ kit (Vector Laboratories, Burlingame, $\mathrm{CA}$ ) and anti- human BMP-2 antibodies prepared by immunizing a rabbit with bacterially expressed human BMP-2. Color was developed with a Konica Immunostaining HRP-1000 (Konica Inc., Tokyo, Japan). In some cases, TCA was added to $1-\mathrm{ml}$ aliquots of the conditioned media to a final concentration of $10 \%$ which were cleared of cellular debris, followed by gentle agitation at $4^{\circ} \mathrm{C}$ for $1 \mathrm{~h}$ and then by centrifugation at $4^{\circ} \mathrm{C}$ for $15 \mathrm{~min}$ at $10,000 \mathrm{~g}$. The precipitates were washed once with $10 \%$ TCA and twice with acetone, and then subjected to Western blots.

Adenovirus-mediated gene transfer to balloon-injured arteries. In vivo gene transfer experiments were performed using 10-wk-old SPF Wistar rats by the method reported previously by Guzman et al. with some modifications (20). All procedures were performed under sterile conditions according to the Guide for Animal Experimentation, Faculty of Medicine, University of Tokyo. General anesthesia was performed by the administration of $90 \mathrm{mg} / \mathrm{kg}$ of ketamine intraperitoneally and $15 \mathrm{mg} / \mathrm{kg}$ of xylazine intramuscularly. Ketamine was supplemented intraperitoneally as necessary. The left carotid artery was exposed and its branches were ligated using 6-0 nylon. After $75 \mathrm{U} / \mathrm{kg}$ of heparin had been injected intravenously, a portion of the external carotid artery and a portion of the internal carotid artery were crossclipped using a microclip (2v-clip; S\&T Inc., Neuhausen, Switzerland). A 2 F Fogarty embolectomy catheter (Baxter, Irvine, CA) was introduced into the artery via an $\sim 3 \mathrm{~mm}$ longitudinal arteriotomy in the external carotid artery. The common carotid arteries were injured by six passes of an embolectomy catheter inflated with $0.2 \mathrm{ml}$ of air. With an additional clip on the proximal portion of the common carotid artery, the arteriotomy was closed with five to seven stitches, using 10-0 nylon, under a magnification of 30 , and then blood flow was resumed by removal of the clips.

At $5 \mathrm{~d}$ after the injury, the adenovirus was transferred to the injured common carotid artery. After the rats had been reanesthetized, the balloon-injured carotid was exposed, and the proximal portion of the common carotid artery and the internal carotid were crossclipped. Then, $50-75 \mu \mathrm{l}$ of virus fluid $\left(1.0 \times 10^{10}\right.$ plaque-forming units $/ \mathrm{ml}$ ) was delivered into a $1.5-\mathrm{cm}$ length of the common carotid artery through the incision made in the external carotid artery using a 24-gauge catheter to fill the lumen, and the portion proximal to the incision was ligated with 7-0 nylon. The virus solutions were diluted with a medium (OPTI-MEM I; Life Technologies Inc.). After incubation for $40 \mathrm{~min}$, the cross-clips were released and the common carotid artery was reperfused.

5-Bromo-4-chloro-3-indolyl- $\beta$ - $D(-)$-galactopyranoside ( $X$-gal) staining. A portion of the left carotid artery, removed $3 \mathrm{~d}$ after the adenoviral infection, was incubated in $5 \mathrm{mM} \mathrm{K}_{4} \mathrm{Fe}(\mathrm{CN})_{6}, 5 \mathrm{mM} \mathrm{K}_{3} \mathrm{Fe}(\mathrm{CN})_{6}$, and $2 \mathrm{mM} \mathrm{MgCl}$ containing X-gal $(0.5 \mathrm{mg} / \mathrm{ml})$ at $37^{\circ} \mathrm{C}$ for $6 \mathrm{~h}$ after fixation in $2 \%$ formaldehyde and $0.2 \%$ glutaraldehyde in PBS at $4{ }^{\circ} \mathrm{C}$ for $1 \mathrm{~h}$. Then, an X-gal-stained artery was refixed in $4 \%$ paraformaldehyde at $4^{\circ} \mathrm{C}$ for $6-12 \mathrm{~h}$ and paraffin-embedded. A section of the paraffin-embedded specimen was stained with hematoxylin and eosin and then analyzed.

Measurement of $\beta$-galactosidase activity. Portions of balloon-injured left carotid arteries were removed at $3 \mathrm{~d}$ after transfection of an adenovirus, AxCALacZ. After briefly washing in PBS, total $\beta$-galactosidase activity of the arteries was measured using a $\beta$-galactosidase enzyme assay system according to the manufacturer's instructions (Promega, Madison, WI). Protein concentrations were determined using a micro BCA protein assay reagent kit (Pierce Chemical Co., Rockford, IL).

Measurement of the intimal and medial cross-sectional areas of a balloon-injured carotid artery. A portion of the left common carotid artery, transfected or untransfected with adenoviruses at $5 \mathrm{~d}$ after the balloon injury, was harvested at $14 \mathrm{~d}$ after the injury. The artery was fixed in PBS containing $4 \%$ paraformaldehyde for $6-12 \mathrm{~h}$ at $4^{\circ} \mathrm{C}$ and then paraffin-embedded. Four round cross-sections per $1.5-\mathrm{cm}$ length of artery specimens stained with hematoxylin and eosin were photographed, and the cross-sectional areas of the intimal and medial regions of the sections were measured using an image analyzing soft- 
ware package (NIH Image). The intimal and medial cross-sectional areas and intimal to medial $(\mathrm{I} / \mathrm{M})$ area ratio of each injured artery were determined by averaging the values for four sections to evaluate the intimal mass in each artery. Some paraffin-embedded sections were stained with Elastica van Gieson to clearly define the extracellular matrix in the injury-induced neointimal region.

Statistical analysis. All data are expressed as means \pm SEM. The unpaired Student's $t$ test was used for comparison of two groups using Statview-J 4.02 (BrainPower, Calabasas, CA). Statistical significance was accepted at $P<0.05$.

\section{Results}

Effects of BMP-2 and TGF- $\beta 1$ on the growth of rat aortic $S M C$ in vitro. To characterize the action of BMP-2 on the growth of cultured SMCs, the effect of BMP-2 on DNA synthesis in SMCs was evaluated and compared with that of TGF- $\beta 1$. The rate of DNA synthesis (estimated as $\left[{ }^{3} \mathrm{H}\right]$ thymidine incorporation into DNA) in SMCs that had been made quiescent by serum starvation started to increase at 14-16 h after stimulation with $1 \%$ FBS, reached a peak at $24 \mathrm{~h}$, and then decreased (Fig. $1 A$ ). TGF- $\beta 1$ at 100 pM inhibited the serumstimulated DNA synthesis at 19 and 24 h by 57 and $30 \%$, respectively $(P<0.01)$. After that, however, the rate of DNA synthesis continued to increase and reached a peak at $32 \mathrm{~h}$, which was comparable with the peak value for serum-stimulated cells without TGF- $\beta 1$ treatment. Thus, TGF- $\beta 1$ apparently delayed the peak of serum-simulated DNA synthesis under these conditions. In contrast, BMP-2 at as low as $0.3 \mathrm{pM}$ strongly inhibited the serum-stimulated DNA synthesis at every time point over $48 \mathrm{~h}(67 \%$ at $19 \mathrm{~h}$ and $47 \%$ at $24 \mathrm{~h}$, respectively; $P<0.01$ at every time point). The inhibitory effect of BMP-2 on DNA synthesis increased dose-dependently up to $0.3 \mathrm{pM}$, with a threshold concentration of $0.03 \mathrm{pM}$ (Fig. $1 B$ ). However, paradoxically, the inhibitory effect of BMP-2 at higher concentrations (3-30 pM) became less pronounced. Inhibitory effect of BMP-2 was observed again at $100 \mathrm{pM}$.

We next examined the effect of BMP-2 added at various time points after serum addition. As shown in Fig. $1 C$, even when BMP-2 was added at $20 \mathrm{~h}$ after serum addition, i.e., after cells had entered the S phase, BMP-2 still inhibited DNA synthesis at $24 \mathrm{~h}(P<0.01)$. In sharp contrast, TGF- $\beta 1$ no longer suppressed the serum-stimulated DNA synthesis when it was added just before (at $13 \mathrm{~h}$ ) or after (at $20 \mathrm{~h}$ ) S phase entry $(P>$ $0.05)$, which is consistent with several previous reports (21-23).

The effect of BMP-2 on the growth of SMCs was evaluated by culturing SMCs in DME containing 10\% FBS, since the doubling time of SMCs in $10 \%$ FBS was shorter than in $1 \%$
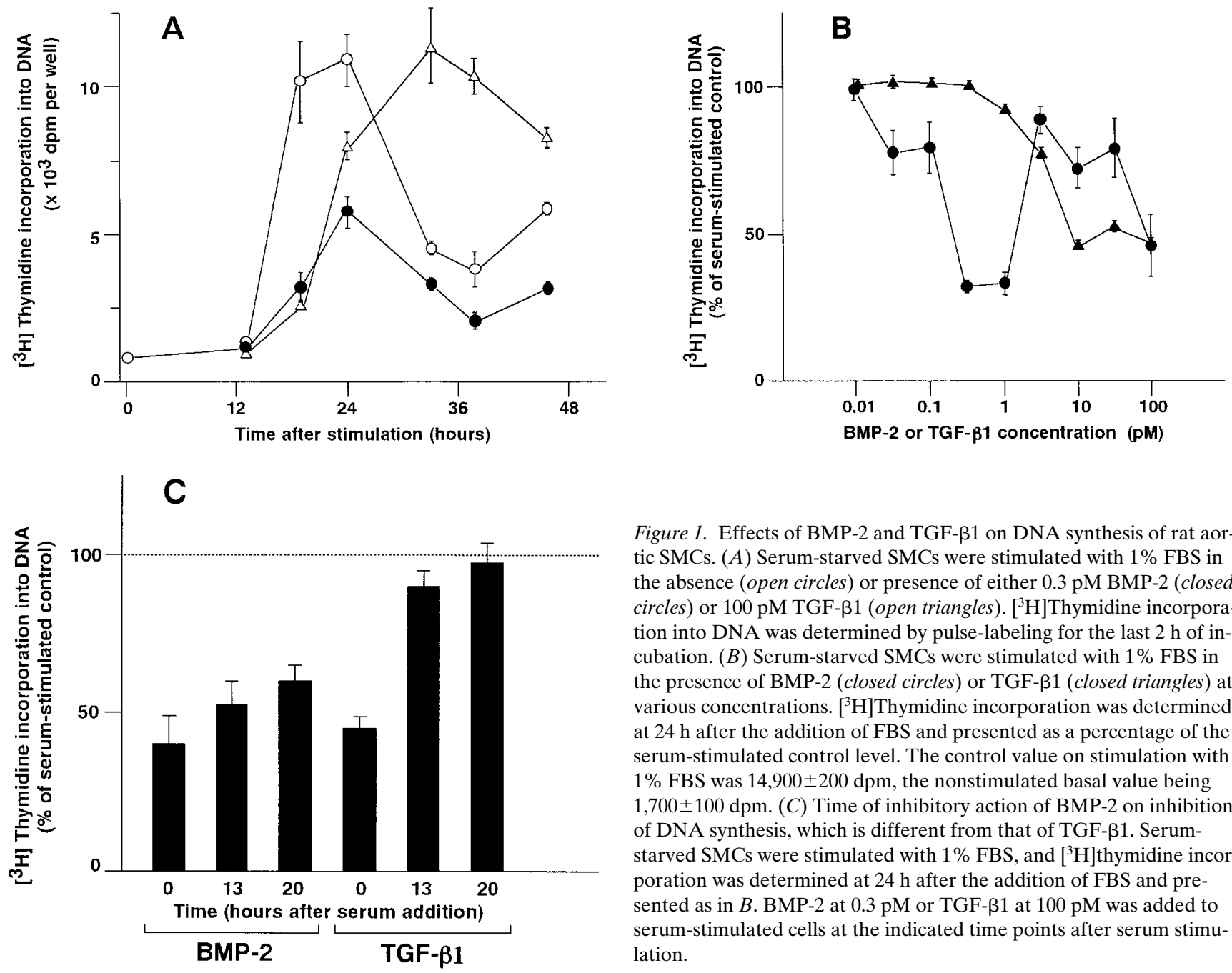

Figure 1. Effects of BMP-2 and TGF- $\beta 1$ on DNA synthesis of rat aortic SMCs. (A) Serum-starved SMCs were stimulated with $1 \%$ FBS in the absence (open circles) or presence of either 0.3 pM BMP-2 (closed circles) or $100 \mathrm{pM}$ TGF- $\beta 1$ (open triangles). $\left[{ }^{3} \mathrm{H}\right]$ Thymidine incorporation into DNA was determined by pulse-labeling for the last $2 \mathrm{~h}$ of incubation. (B) Serum-starved SMCs were stimulated with $1 \%$ FBS in the presence of BMP-2 (closed circles) or TGF- $\beta 1$ (closed triangles) at various concentrations. $\left[{ }^{3} \mathrm{H}\right]$ Thymidine incorporation was determined at $24 \mathrm{~h}$ after the addition of FBS and presented as a percentage of the serum-stimulated control level. The control value on stimulation with $1 \%$ FBS was $14,900 \pm 200 \mathrm{dpm}$, the nonstimulated basal value being $1,700 \pm 100 \mathrm{dpm} .(C)$ Time of inhibitory action of BMP-2 on inhibition of DNA synthesis, which is different from that of TGF- $\beta 1$. Serumstarved SMCs were stimulated with $1 \% \mathrm{FBS}$, and $\left[{ }^{3} \mathrm{H}\right]$ thymidine incorporation was determined at $24 \mathrm{~h}$ after the addition of FBS and presented as in B. BMP- 2 at $0.3 \mathrm{pM}$ or TGF- $\beta 1$ at $100 \mathrm{pM}$ was added to serum-stimulated cells at the indicated time points after serum stimulation. 

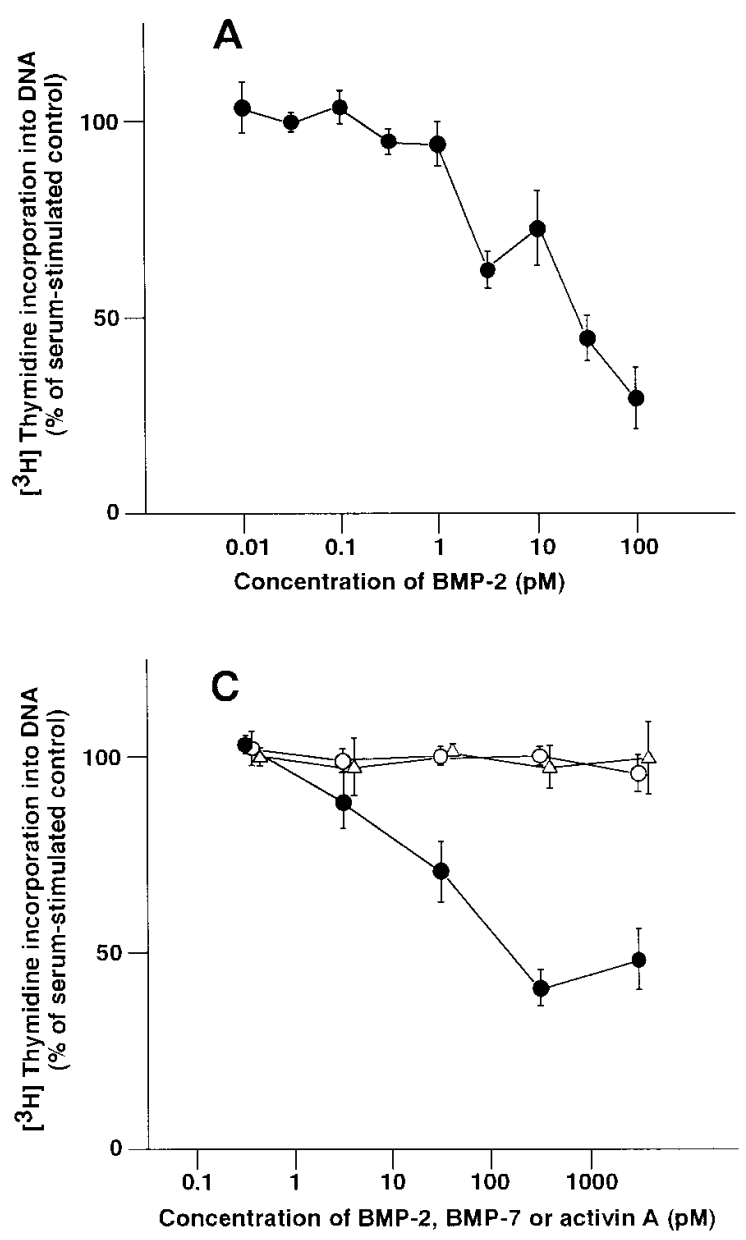

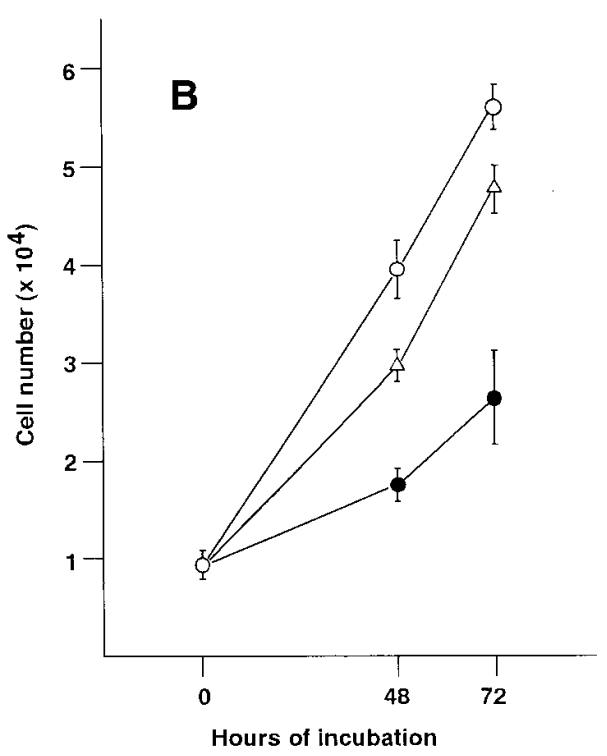

Figure 2. Inhibition of the increase in cell number together with DNA synthesis in rat aortic SMCs by BMP-2. (A) Serum-starved SMCs were stimulated with $10 \%$ FBS in the presence of BMP-2 at various concentrations. $\left[{ }^{3} \mathrm{H}\right]$ Thymidine incorporation was determined at $24 \mathrm{~h}$ after the addition of FBS and presented as a percentage of the serum-stimulated control level. The control value on stimulation with $10 \%$ FBS was 49,000 $\pm 1,300$ dpm. (B) SMCs seeded onto 24well plates at $8 \times 10^{3}$ cells per well were maintained in DME containing $10 \%$ FBS for $24 \mathrm{~h}$ for their attachment to the plates. Then the medium was replaced, and the cells were grown in $10 \%$ FBS alone (open circles) or with either $100 \mathrm{pM}$ BMP-2 (closed circles) or $100 \mathrm{pM}$ TGF- $\beta 1$ (open triangles) for $3 \mathrm{~d}$. The total cell numbers were determined using a hemocytometer, by harvesting

cells at 0,48 , and $72 \mathrm{~h}$ after medium replacement and cell viability was $>95 \%$ at the end of the experiment. $(C)$ Serum-starved SMCs were stimulated with $10 \%$ FBS in the presence of BMP-2 (closed circles), BMP-7 (open circles), or activin A (open triangles) at various concentrations. $\left[{ }^{3} \mathrm{H}\right]$ Thymidine incorporation was determined at $24 \mathrm{~h}$ after the addition of FBS and presented as a percentage of the serum-stimulated control level. The results are representative of three separate experiments.

FBS. BMP-2 also inhibited the DNA synthesis in SMCs at $24 \mathrm{~h}$ after stimulation with $10 \%$ FBS $(P<0.01$ at 100 pM, Fig. $2 A)$. The cell number of SMCs grown with 100 pM BMP-2 was decreased, as compared with that of SMCs grown without BMP-2, by $68 \%$ on day $2(P<0.01)$ and by $59 \%$ on day $3(P<0.05)$, respectively (Fig. $2 B$ ). On the other hand, the increase in the number of the cells treated with TGF- $\beta 1$ was decreased only by $24 \%$, as compared with the control culture $(P<0.05)$. Thus, consistent with the inhibition of DNA synthesis, BMP-2 also inhibited the increase in the cell number of SMCs grown in the presence of serum. The dose-effect relationship between BMP-2 and inhibition of DNA synthesis stimulated with $10 \%$ FBS was dose-dependent up to $3 \mathrm{nM}$ unlike the case with $1 \%$ FBS (Fig. $2 C$ ). We also examined the effect of BMP-7 and activin A, members of the TGF- $\beta$ superfamily, on DNA synthesis stimulated with $10 \%$ FBS; however, they did not significantly inhibit DNA synthesis stimulated with $10 \%$ FBS.

Effects of BMP-2 and TGF- $\beta 1$ on collagen synthesis by $S M C s$. Excessive extracellular matrix synthesis is one of the features of atherosclerosis, and TGF- $\beta 1$ has the ability to stimulate the synthesis of extracellular matrix components such as collagen and proteoglycan by cultured SMCs $(24,25)$. There- fore, we examined whether or not BMP-2 has a stimulatory action on collagen synthesis by SMCs similar to that of TGF- $\beta 1$. TGF- $\beta 1$ stimulated collagen synthesis by $17 \%$ at $10 \mathrm{pM}(P<$ $0.05)$ and by $40 \%$ at $100 \mathrm{pM}(P<0.01)$. In contrast, BMP-2 at up to $1 \mathrm{nM}$ did not stimulate collagen synthesis by SMCs (Fig. 3).

Effect of adenovirus-mediated transfer of the BMP-2 gene on DNA synthesis of cultured SMCs. To examine the effect of BMP-2 gene transfer into SMCs on their proliferation, we constructed a replication-deficient adenovirus carrying the BMP-2 gene under the control of the CAG promoter, AxCABMP2. The rate of DNA synthesis was evaluated in cultured SMCs which had been transfected with a virus, either AxCABMP2 or AxCALacZ. SMCs that had been infected with AxCABMP2 at 3-24 mois showed a lower rate of DNA synthesis in response to serum stimulation, as compared with mock-infected control cells (lowest at 12 moi of AxCABMP2, 21\% of control, $P<0.001$ ) (Fig. 4). In contrast to this, infection of cells with AxCALacZ at the same mois did not inhibit the serum-stimulated DNA synthesis. Inhibition of DNA synthesis in SMCs by AxCABMP2 was reduced by $>24$ moi, and the dose-effect relationship between AxCABMP2 and DNA synthesis gave a concave curve. 


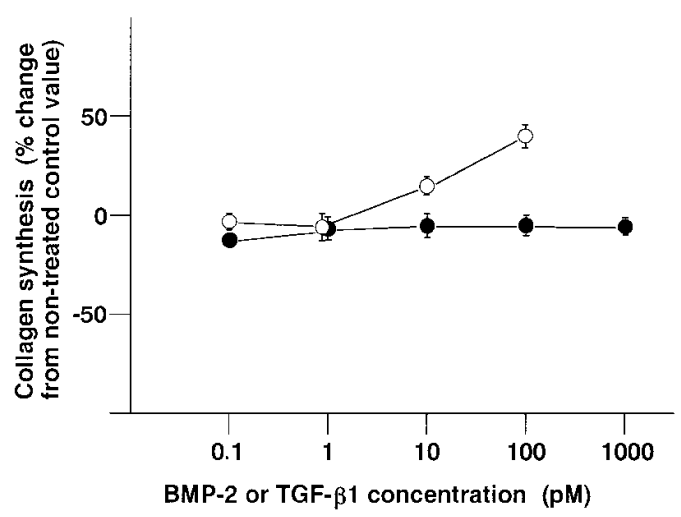

Figure 3. Collagen synthesis by rat aortic SMCs is upregulated by TGF- $\beta 1$ but not by BMP-2. SMCs were treated with the indicated concentrations of BMP-2 (closed circles) or TGF- $\beta 1$ (open circles), and then labeled with $\left[{ }^{3} \mathrm{H}\right]$ proline for $3 \mathrm{~h}$. Collagen synthesis by cells was determined and presented as percent difference from

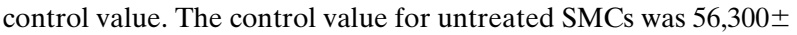
$2,900 \mathrm{dpm}$.

Production of the BMP-2 protein was examined by Western blot analysis. Anti-BMP-2 antibodies used in this study clearly detected $5 \mathrm{ng}$ recombinant BMP-2, but not $30 \mathrm{ng}$ TGF$\beta 1$, activin A, or BMP-7 (data not shown). This suggests that the antibody is highly specific to BMP-2. BMP-2 produced by SMCs is expected to be secreted into the extracellular space, since the BMP-2 gene possesses a signal peptide sequence. A $20-\mathrm{kD}$ protein that reacted with anti-BMP-2 antibody was detected in conditioned medium of SMCs infected with AxCABMP2 at 200 moi, but not in medium of mock-infected cells or cells infected with AxCALacZ (Fig. $5 A$ ). Its mobility on SDS-PAGE slightly differed from those of recombinant human BMP-2 purified from the Chinese hamster ovary $(\mathrm{CHO})$

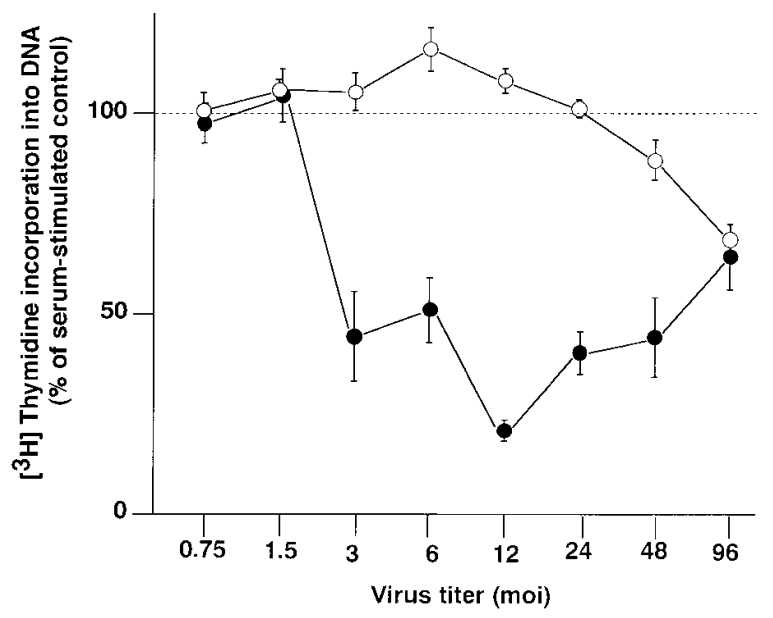

Figure 4. Inhibition of DNA synthesis in vitro on adenovirus-mediated transfer of the BMP-2 gene. Rat aortic SMCs seeded onto a 24well plate were exposed to $200 \mu \mathrm{l}$ of DME containing $0.5 \%$ FBS and the indicated mois of either AxCABMP2 (closed circles) or AxCALacZ (open circles) for $2 \mathrm{~h}$, and were serum-deprived for $60 \mathrm{~h}$.

$\left[{ }^{3} \mathrm{H}\right]$ Thymidine incorporation into DNA was determined at $24 \mathrm{~h}$ after the stimulation with $1 \%$ FBS and presented as a percentage of the serum-stimulated control level.
A

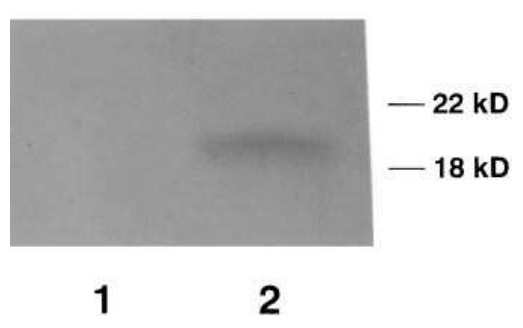

B

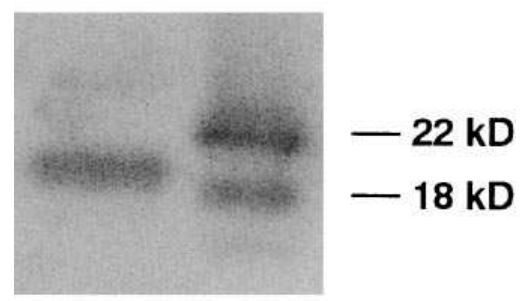

34

cell line stably producing human BMP-2, which consists of 18and 22-kD subspecies; 22-kD being a major band (Fig. $5 \mathrm{~B}$ ). When $\mathrm{CHO}$ cells were infected with AxCABMP2 and conditioned media were analyzed, we detected a 22-kD band, which was similar to the 22-kD subspecies of recombinant BMP-2 (data not shown). These data indicate that the cells infected with AxCABMP2 might produce BMP-2 proteins with different mobility on SDS-PAGE, depending on the type of the infected cells.

To delineate the amount of BMP-2 secreted by SMCs infected with AxCABMP2, conditioned media of infected cells were treated with TCA and the precipitates were evaluated by Western blot analysis. A $20-\mathrm{kD}$ band was not detected in the conditioned media of SMCs infected with AxCABMP2 at 48 moi or less. Therefore, the concentration of BMP-2 in the conditioned media of SMC infected with AxCABMP2, at mois at which DNA synthesis in infected cells was inhibited, was $<100$ $\mathrm{pM}$, since $100 \mathrm{pM}$ BMP-2 in $1 \mathrm{ml}$ of cultured medium should have been detected with this procedure.

Inhibition of balloon injury-induced intimal hyperplasia by AxCABMP2. We next tried to determine whether or not BMP-2 can inhibit in vivo vascular smooth muscle proliferation as well. To this end, we used a rat carotid balloon injury model and examined the effect of the adenovirus-mediated transfer of the $B M P-2$ gene upon injury-induced intimal SMC hyperplasia. We first determined the efficacy of expression of genes transferred by the adenovirus vector using AxCALacZ. Similar to the previous report (20), nearly $50 \%$ or more of the neointimal cells in a balloon-injured carotid artery expressed the $\beta$-galactosidase gene, as estimated by X-gal staining of injured arteries transfected with AxCALacZ (Fig. $6 A$ ). Tissue $\beta$-galactosidase activity was $>50$-fold higher in injured carotid 


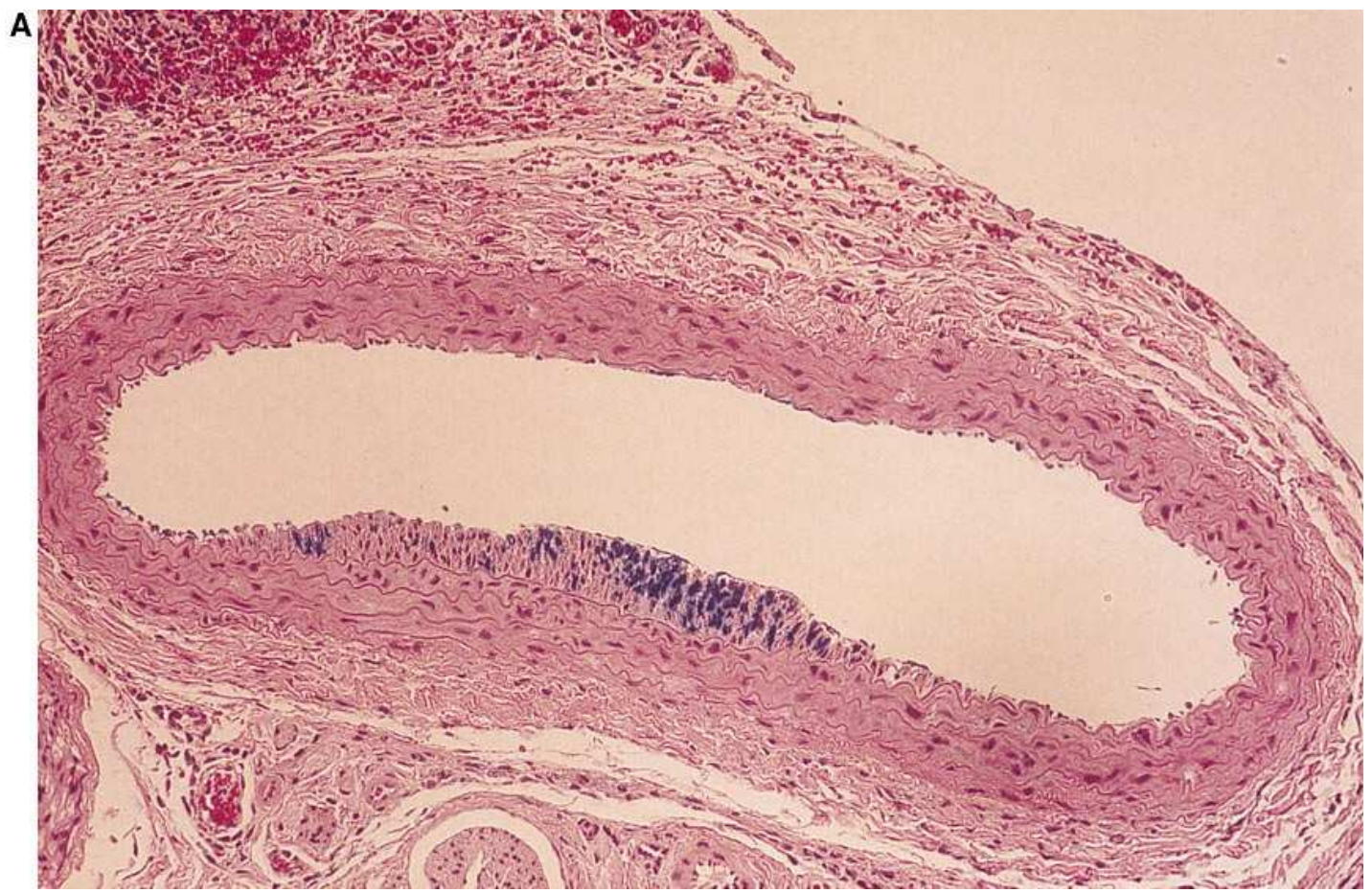

Figure 6. Inhibition of balloon injury induced neointimal hyperplasia on adenovirus-mediated transfer of the BMP-2 gene. The ballooninjured arteries were transfected or untransfected with adenoviruses $5 \mathrm{~d}$ later. The portions of the arteries were removed $3 \mathrm{~d}$ after the transfection with AxCALacZ to analyze $\beta$-galactosidase expression $(A)$ or harvested $14 \mathrm{~d}$ after the injury to analyze neointimal formation $(B$ and $C)$. Paraffinembedded specimens were treated as in the text. $(A)$ An X-gal, hematoxylin and eosinstained section of the artery transfected with AxCALacZ, showing an intense $\beta$-galactosidase activity in the forming neointimal region. (B) Representative Elastica van Gieson-stained cross-sections of a control balloon-injured artery (Control), an injured artery transfected with AxCABMP2, and an injured artery transfected with AxCALacZ. Bars, $100 \mu \mathrm{m}$. Original magnification, $\times 25$. (C) Intimal (top) and medial (middle) cross-sectional areas, as well as I/M area ratios (bottom) of untreated and treated rat carotid arteries. Data are means \pm SEM. Control, Balloon-injured control artery $(n=6)$; AxCABMP2, balloon-injured artery transfected with AxCABMP2 $(n=9)$; and AxCALacZ, balloon-injured artery transfected with AxCALacZ $(n=6)$.

arteries exposed to the virus at $5 \mathrm{~d}$ after injury than immediately after the injury (data not shown).

We introduced either AxCABMP2 or AxCALacZ at $10^{10}$ plaque-forming units/ml into injured rat left carotid arteries at $5 \mathrm{~d}$ after balloon injury. $14 \mathrm{~d}$ after balloon injury, the injured arteries were harvested to measure the cross-sectional areas of the intima and media of each artery and the I/M area ratio (Fig. 6, $B$ and $C$ ). The administration of AxCABMP2 reduced the intimal mass of an injured artery by $41 \%$, as compared with the administration of AxCALacZ $(P<0.01)$. However, the medial mass was similar in the two groups. As a result, the $\mathrm{I} / \mathrm{M}$ area ratio was substantially reduced on the administration of AxCABMP2 $(P<0.002)$. Thus, an adenovirus encoding the $B M P-2$ gene can effectively limit intimal hyperplasia after balloon injury.

\section{Discussion}

This paper is the first to document that BMP-2 is a potent inhibitor of SMC proliferation both in vitro and in vivo. BMP-2 was growth-inhibitory at relatively low concentrations (0.03-1 $\mathrm{pM}$ ), without inducing delayed DNA synthesis. These concentrations are lower than those required for other biological activities of BMPs, such as the induction of osteoblastic differentiation (26). However, it has been reported that BMP-4, a very closely related homologue of BMP-2, induced the migration of human blood monocytes at far lower concentrations than in our study (i.e. 0.3-3 fM) (27). Since BMPs use multiple receptor systems depending on the cell types and their various bio- logical effects (28), the difference in effective doses of BMPs may be due to receptors expressed on the cells and sensitivities of the assays used in these studies. In our study, the doseeffect relationship of DNA synthesis in $10 \%$ FBS was different from that in $1 \%$ FBS. It has been reported that the growth inhibition of human embryonic carcinoma cells by BMP-7 is affected by the concentration of FBS in the culture medium (9). It might be that serum contains a counteracting activity towards BMPs, as in the case of follistatin, a binding protein of activin (29). The concentration of BMP-2 required for maximal growth inhibition was far lower than those of previously known growth inhibitors of SMC such as natriuretic peptides and 8-bromo-cyclic guanosine monophosphate (4).

TGF- $\beta 1$ induces $G_{1}$ arrest in some cells such as Mv1Lu cells through its action towards these cells in the late $\mathrm{G}_{1}$ phase (30). The growth-inhibitory action of BMP-2 on SMCs is different from that of TGF- $\beta 1$ at least in the time order of their actions, since BMP-2 was active when added later, as shown in Fig. $1 C$. Consistent with the suppressive activity of BMP-2 toward serum-stimulated DNA synthesis, BMP-2 inhibited the increase in cell number in the presence of serum. It has been reported that activin A, another member of TGF- $\beta$ superfamily, has a growth-stimulatory effect on the proliferation of SMCs (31). In our study, however, activin A did not affect DNA synthesis in SMCs, probably due to the different experimental conditions. It is noteworthy that BMP-7 partially mimicked the action of BMP-2 under low serum concentration, since BMP-7 at $100 \mathrm{pM}$ or more inhibited DNA synthesis stimulated with $1 \%$ FBS (Nakaoka, T., K. Miyazono, and T. Fujita, 
B
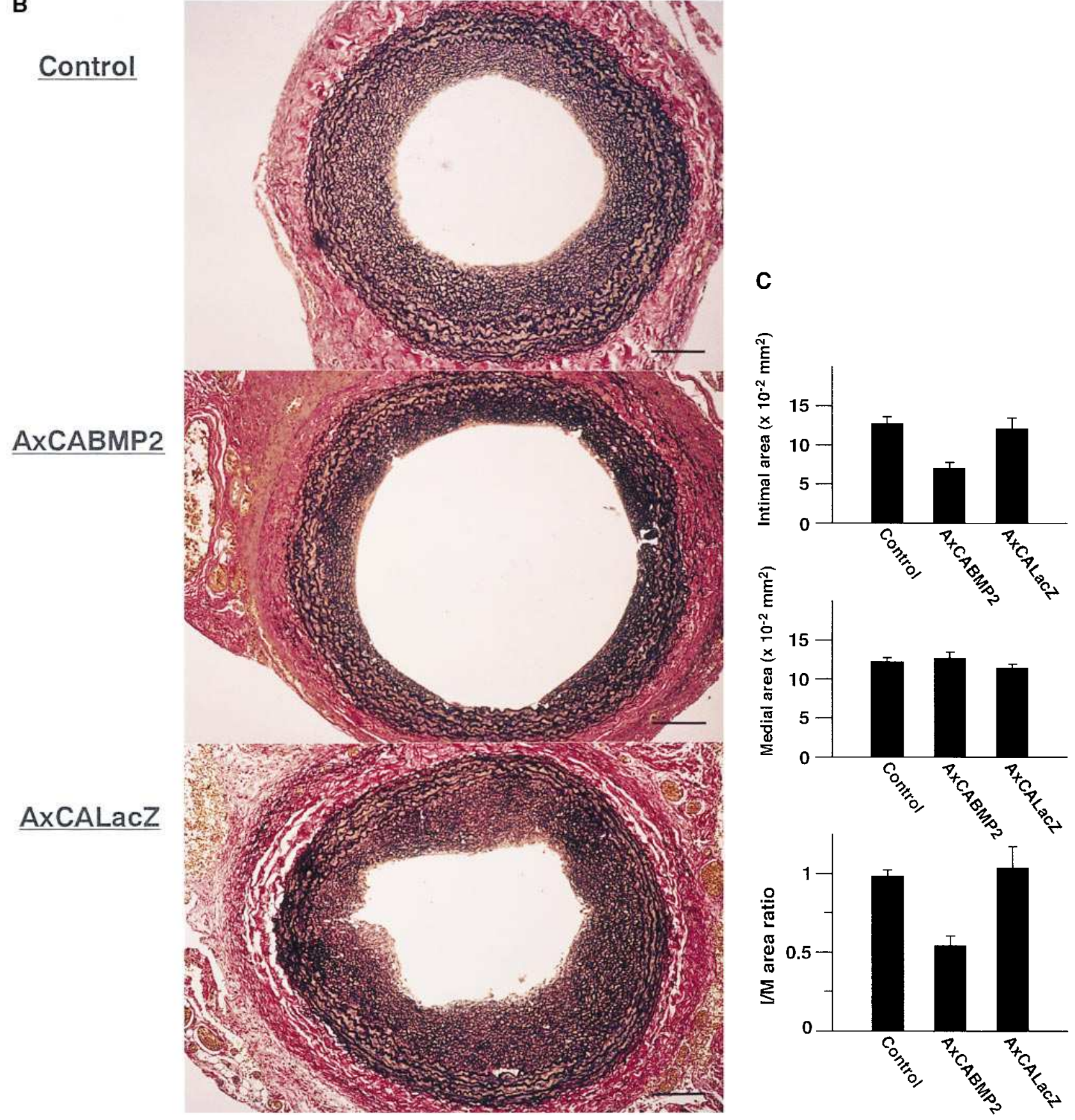

Figure 6 (Continued)

unpublished observation), although BMP-7 did not inhibit DNA synthesis under high serum concentration. It has been reported that $S m a d 1$ acts downstream as a transcriptional activator in signaling by members of the BMP subfamily (32). It should be determined whether or not Smad pathways are involved in the BMP-2-induced inhibition of S phase entry and S phase progression.

Furthermore importantly, BMP-2 up to $1 \mathrm{nM}$ did not stimulate collagen synthesis at all. Thus, the action of BMP toward cultured SMCs is different from that of TGF- $\beta 1$ in the effect on collagen synthesis as well as the mode of growth inhibition. Previous studies implicated TGF- $\beta 1$ in the increased synthesis of extracellular matrix component in atherosclerotic lesions and in restenotic lesions after balloon angioplasty $(33,34)$, although TGF- $\beta 1$ inhibits the serum-stimulated growth of cultured SMCs. The ability of BMP-2 to act as a potent inhibitor of SMC proliferation without stimulating the synthesis of collagen, a major extracellular matrix protein, is considered to be favorable for in vivo application to therapy for vascular proliferative disorders.

Rat aortic SMCs infected with AxCABMP2 produced BMP-2 with different mobility on SDS-PAGE from those of recombinant human BMP-2 purified from the $\mathrm{CHO}$ cell line stably producing human BMP-2. It has been reported that mature recombinant BMP-2 protein produced in $\mathrm{CHO}$ cells contains high mannose and complex $\mathrm{N}$-linked oligosaccharide and 
that 18 - and $22-\mathrm{kD}$ subspecies differ by proteolytic processing at their amino termini (35). Moreover, the $\mathrm{CHO}$ cells and the SMCs infected with the same adenovirus, AxCABMP2, produced different species of BMP-2 proteins as shown in Fig. 5. Thus, the difference in the mobility in SDS-PAGE might be due to different amino-terminal processing or carbohydrate structure in the mature BMP-2 proteins, which may be dependent on the transfected cells.

BMP-2 was originally identified by its bone formation activity (7). However, histological examination did not reveal any osseous or cartilaginous change in injured arterial tissue infected with AxCABMP2. The expression of a protein through adenovirus-mediated gene transfer is transient in nature. Local expression of BMP-2 for a longer time may predispose an arterial wall to an osseous change. Considering BMP-2 is now recognized as a widely acting differentiation-inducing factor (8), its role as a differentiation factor in vascular proliferative lesions might deserve attention from quite a different viewpoint. It is known that neointimal SMCs shows a synthetic phenotype different from the contractile phenotype of medial SMCs (1). Therefore, it would be interesting to determine whether and how the expression of BMP-2 affects the smooth muscle phenotype, especially in the neointima.

Since the proliferation of SMCs is an essential feature of vascular proliferative disorders, considerable effort has been made to develop a therapeutic strategy to effectively suppress SMC proliferation. Previous attempts to suppress SMC proliferation have included the administration of antibodies against growth factors, antagonists for receptors, and antisense oligonucleotides directed to transcription factors and cell cycle regulatory molecules required for cell proliferation (36-38). More recent studies demonstrated that the adenovirus-mediated transfer of a therapeutic gene into the vascular wall could be a promising treatment strategy. For example, it was reported that considerable inhibition of intimal hyperplasia was observed on the administration of an adenovirus containing herpes simplex virus thymidine kinase gene with the prodrug ganciclovir (39-41), an adenovirus containing the gene of the thrombin inhibitor, hirudin (42), and an adenovirus containing the gene of a constitutively active form of the retinoblastoma gene product (43). In the case of the $B M P-2$ gene, neighboring untransfected cells in the vascular wall may also be affected by diffusible BMP-2, a "bystander effect," since BMP-2 is a secreted protein. The ability of BMP-2 as a growth inhibitor described above makes this molecule a suitable candidate therapeutic agent for the prevention of vascular proliferative disorders.

\section{Acknowledgments}

We wish to thank Dr. T. Kuber Sampath (Creative BioMolecules, Hopkinton, MA) for the recombinant human BMP-2 and BMP-7; Dr. Izumu Saito (Institute of Medical Science, University of Tokyo) for the adenoviruses, Ad5dlx and AxCALacZ, and a cosmid, pAxcw; Dr. Jun-ichi Miyazaki (Institute of Development, Aging and Cancer, Tohoku University) for the expression vector, pCAGGS; Dr. Yuzuru Eto (Central Research Laboratories, Ajinomoto Co., Inc.) for recombinant human activin A; and Dr. Tsutomu Nishizawa (High Quality Life Research Laboratories, Sumitomo Metal Industries, Ltd.) for the anti-human BMP-2 antibody. We also thank Dr. Jun-ichi Taguchi (University of Tokyo) for helpful discussions, Dr. Jun-o Deguchi (University of Tokyo) for technical advice regarding the balloon injury experiment, and Ms. Nobue Fujii for technical assistance.
This work was supported by grants-in-aid for the Encouragement of Young Scientists to T. Nakaoka from the Japanese Ministry of Education.

\section{References}

1. Ross, R. 1993. The pathogenesis of atherosclerosis: a perspective for the 1990s. Nature. 362:801-809.

2. Brown, G., J.J. Albers, L.D. Fisher, S.M. Schaefer, J.T. Lin, C. Kaplan, X.Q. Zhao, B.D. Bisson, V.F. Fitzpatrick, and H.T. Dodge. 1990. Regression of coronary artery disease as a result of intensive lipid-lowering therapy in men with high levels of apolipoprotein B. N. Engl. J. Med. 323:1289-1298.

3. Hansson, G.K., M. Hellstrand, L. Rymo, L. Rubbia, and G. Gabbiani. 1989. Interferon $\gamma$ inhibits both proliferation and expression of differentiationspecific $\alpha$-smooth muscle actin in arterial smooth muscle cells. J. Exp. Med. 170: 1595-1608.

4. Garg, U.C., and A. Hassid. 1989. Nitric oxide-generating vasodilators and 8-bromo-cyclic guanosine monophosphate inhibit mitogenesis and proliferation of cultured rat vascular smooth muscle cells. J. Clin. Invest. 83:1774-1777.

5. Majack, R.A. 1987. Beta-type transforming growth factor specifies organizational behavior in vascular smooth muscle cell cultures. J. Cell Biol. 105: $465-471$.

6. Battegay, E.J., E.W. Raines, R.A. Seifert, D.F. Bowen-Pope, and R. Ross. 1990. TGF- $\beta$ induces bimodal proliferation of connective tissue cells via complex control of an autocrine PDGF loop. Cell. 63:515-524.

7. Wozney, J.M., V. Rosen, A.J. Celeste, L.M. Mitsock, M.J. Whitters, R.W. Kriz, R.M. Hewick, and E.A. Wang. 1988. Novel regulators of bone formation: molecular clones and activities. Science. 242:1528-1534.

8. Hogan, B.L.M. 1996. Bone morphogenetic proteins: multifunctional regulators of vertebrate development. Genes Dev. 10:1580-1594.

9. Andrews, P.W., I. Damjanov, J. Berends, S. Kumpf, V. Zappavigna, F. Mavilio, and T.K. Sampath. 1994. Inhibition of proliferation and induction of differentiation of pluripotent human embryonal carcinoma cells by osteogenic protein-1 (or bone morphogenetic protein-7). Lab. Invest. 71:243-251.

10. Yamashita, H., P. ten Dijke, D. Huylebroeck, T.K. Sampath, M. Andries, J.C. Smith, C.-H. Heldin, and K. Miyazono. 1995. Osteogenic protein-1 binds to activin type II receptors and induces certain activin-like effects. J. Cell Biol. 130:217-226.

11. Boström, K., K.E. Watson, S. Horn, C. Wortham, I.M. Herman, and L.L. Demer. 1993. Bone morphogenetic protein expression in human atherosclerotic lesions. J. Clin. Invest. 91:1800-1809.

12. Schluesener, H.J., and R. Meyermann. 1995. Immunolocalization of BMP-6, a novel TGF- $\beta$-related cytokine, in normal and atherosclerotic smooth muscle cells. Atherosclerosis. 113:153-156.

13. Kanegae, Y., G. Lee, Y. Sato, M. Tanaka, M. Nakai, T. Sakaki, S. Sugano, and I. Saito. 1995. Efficient gene activation in mammalian cells by using recombinant adenovirus expressing site-specific Cre recombinase. Nucl. Acids Res. 23:3816-3821.

14. Niwa, H., K. Yamamura, and J.-i. Miyazaki. 1991. Efficient selection for high-expression transfectants with a novel eukaryotic vector. Gene. 108:193200.

15. Saito, I., Y. Oya, K. Yamamoto, T. Yuasa, and H. Shimojo. 1985. Construction of nondefective adenovirus type 5 bearing a 2.8-kilobase hepatitis B virus DNA near the right end of its genome. J. Virol. 54:711-719.

16. Miyake, S., M. Makimura, Y. Kanegae, S. Harada, Y. Sato, K. Takamori, C. Tokuda, and I. Saito. 1996. Efficient generation of recombinant adenoviruses using adenovirus DNA-terminal protein complex and a cosmid bearing the full-length virus genome. Proc. Natl. Acad. Sci. USA. 93:1320-1324.

17. Kanegae, Y., M. Makimura, and I. Saito. 1994. A simple and efficient method for purification of infectious recombinant adenovirus. Jpn. J. Med. Sci. Biol. 47:157-166.

18. Chamley-Campbell, J., G.R. Campbell, and R. Ross. 1979. The smooth muscle cell in culture. Physiol. Rev. 59:1-61.

19. Takuwa, Y., C. Ohse, E.A. Wang, J.M. Wozney, and K. Yamashita. 1991. Bone morphogenetic protein-2 stimulates alkaline phosphatase activity and collagen synthesis in cultured osteoblastic cells, MC3T3-E1. Biochem. Biophys. Res. Commun. 174:96-101.

20. Guzman, R.J., P. Lemarchand, R.G. Crystal, S.E. Epstein, and T. Finkel. 1993. Efficient and selective adenovirus-mediated gene transfer into vascular neointima. Circulation. 88:2838-2848.

21. Owens, G.K., A.A. Geisterfer, Y.W. Yang, and A. Komoriya. 1988 Transforming growth factor- $\beta$-induced growth inhibition and cellular hypertrophy in cultured vascular smooth muscle cells. J. Cell Biol. 107:771-780.

22. Grainger, D.J., P.R. Kemp, C.M. Witchell, P.L. Weissberg, and J.C. Metcalfe. 1994. Transforming growth factor $\beta$ decreases the rate of proliferation of rat vascular smooth muscle cells by extending the $G_{2}$ phase of the cell cycle and delays the rise in cyclic AMP before entry into M phase. Biochem. J. 299:227-235.

23. Morisaki, N., M. Kawano, N. Koyama, T. Koshikawa, K. Umemiya, Y. Saito, and S. Yoshida. 1991. Effects of transforming growth factor- $\beta 1$ on growth of aortic smooth muscle cells. Atherosclerosis. 88:227-234. 
24. Chen, J.-K., H. Hoshi, and W.L. McKeehan. 1987. Transforming growth factor type $\beta$ specifically stimulates synthesis of proteoglycan in human adult arterial smooth muscle cells. Proc. Natl. Acad. Sci. USA. 84:5287-5291.

25. Lawrence, R., D.J. Hartmann, and G.E. Sonenshein. 1994. Transforming growth factor $\beta 1$ stimulates type $\mathrm{V}$ collagen expression in bovine vascular smooth muscle cells. J. Biol. Chem. 269:9603-9609.

26. Yamaguchi, A., T. Katagiri, T. Ikeda, J.M. Wozney, V. Rosen, E.A. Wang, A.J. Kahn, T. Suda, and S. Yoshiki. 1991. Recombinant human bone morphogenetic protein-2 stimulates osteoblastic maturation and inhibits myogenic differentiation in vitro. J. Cell Biol. 113:681-687.

27. Cunningham, N.S., V. Paralkar, and A.H. Reddi. 1992. Osteogenin and recombinant bone morphogenetic protein $2 \mathrm{~B}$ are chemotactic for human monocytes and stimulate transforming growth factor $\beta 1$ mRNA expression. Proc. Natl. Acad. Sci. USA. 89:11740-11744.

28, ten Dijke, P., H. Yamashita, T.K. Sampath, A.H. Reddi, M. Estevez, D.L. Riddle, H. Ichijo, C.-H. Heldin, and K. Miyazono. 1994. Identification of type I receptors for osteogenic protein-1 and bone morphogenic protein-4. J. Biol. Chem. 269:16985-16988.

29. Nakamura, T., K. Takio, Y. Eto, H. Shibai, K. Titani, and H. Sugino. 1990. Activin-binding protein from rat ovary is follistatin. Science. 247:836-838.

30. Saltis, J. 1996. TGF- $\beta$ : receptors and cell cycle arrest. Mol. Cell. Endocrinol. 116:227-232.

31. Kojima, I., H. Mogami, N. Kawamura, H. Yasuda, and H. Shibata. 1993. Modulation of growth of vascular smooth muscle cells by activin A. Exp. Cell Res. 206:152-156.

32. Liu, F., A. Hata, J.C. Baker, J. Doody, J. Carcamo, R.M. Harland, and J. Massague. 1996. A human Mad protein acting as a BMP-regulated transcriptional activator. Nature. 381:620-623.

33. Nikol, S., J.M. Isner, J.G. Pickering, M. Kearney, G. Leclerc, and L. Weir. 1992. Expression of transforming growth factor- $\beta 1$ is increased in human vascular restenosis lesions. J. Clin. Invest. 90:1582-1592.

34. Majesky, M.W., V. Lindner, D.R. Twardzik, S.M. Schwartz, and M.A. Reidy. 1991. Production of transforming growth factor $\beta 1$ during repair of arte- rial injury. J. Clin. Invest. 88:904-910.

35. Israel, D.I., J. Nove, K.M. Kerns, I.K. Moutsatsos, and R.J. Kaufman. 1992. Expression and characterization of bone morphogenetic protein-2 in Chinese hamster ovary cells. Growth Factors. 7:139-150.

36. Ferns, G.A., E.W. Raines, K.H. Sprugel, A.S. Motani, M.A. Reidy, and R. Ross. 1991. Inhibition of neointimal smooth muscle accumulation after angioplasty by an antibody to PDGF. Science. 253:1129-1132.

37. Simons, M., E.R. Edelman, J.-L. DeKeyser, R. Lange, and R.D. Rosenberg. 1992. Antisense C-myb oligonucleotides inhibit arterial smooth muscle cell accumulation in vivo. Nature. 359:67-70.

38. Indolfi, C., E.V. Avvedimento, A. Rapacciuolo, E. Di Lorenzo, G. Esposito, E. Stabile, A. Feliciello, E. Mele, P. Giuliano, G. Condorelli, and M. Chiariello. 1995. Inhibition of cellular ras prevents smooth muscle cell proliferation after vascular injury in vivo. Nat. Med. 1:541-545.

39. Ohno, T., D. Gordon, H. San, V.J. Pompili, M.J. Imperiale, G.J. Nabel, and E.G. Nabel. 1994. Gene therapy for vascular smooth muscle cell proliferation after arterial injury. Science. 265:781-784.

40. Guzman, R.J., E.A. Hirschowitz, S.L. Brody, R.G. Crystal, S.E. Epstein, and T. Finkel. 1994. In vivo suppression of injury-induced vascular smooth muscle cell accumulation using adenovirus-mediated transfer of the herpes simplex virus thymidine kinase gene. Proc. Natl. Acad. Sci. USA. 91:10732-10736.

41. Chang, M.W., T. Ohno, D. Gordon, M.M. Lu, G.J. Nabel, E.G. Nabel and J.M. Leiden. 1995. Adenovirus-mediated transfer of the herpes simplex virus thymidine kinase gene inhibits vascular smooth muscle cell proliferation and neointima formation following balloon angioplasty of the rat carotid artery Mol. Med. 1:172-181.

42. Rade, J.J., A.H. Schulick, R. Virmani, and D.A. Dichek. 1996. Local adenoviral-mediated expression of recombinant hirudin reduces neointima formation after arterial injury. Nat. Med. 2:293-298.

43. Chang, M.W., E. Barr, J. Seltzer, Y.-Q. Jiang, G.J. Nabel, E.G. Nabel, M.S. Parmacek, and J.M. Leiden. 1995. Cytostatic gene therapy for vascular proliferative disorders with constitutively active form of the retinoblastoma gene product. Science. 267:518-522. 